\title{
日本海底層の食物網における 有機スズ化合物の生物濃縮
}

\author{
池田久美子 ${ }^{1)}$, 南 卓志 ${ }^{2)}$ ，山田 久 ${ }^{1)}$, 小山 次朗 ${ }^{3)}$ \\ 1)独立行政法人水産総合研究センター 瀬戸内海区水産研究所 \\ （７39-0452 広島県佐伯郡大野町丸石2-17-5） \\ 2)独立行政法人水産総合研究センター 日本海区水産研究所

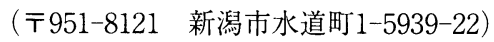 \\ ${ }^{3}$ 鹿児島大学水産学部 海洋資源環境教育研究センター \\ （テ890-0056＼cjkstart鹿児島市下荒田4-50-20）
}

[平成13年12月17日受理］

\section{Bioaccumulation of Organotin Compounds through the Food Web developed in the Deep Water of Japan Sea}

\author{
${\text { Kumiko } \text { IKEDA }^{1)} \text {, Takashi MINAMI }}^{2)}$, Hisashi YAMADA $^{1)}$ and Jiro KOYAMA ${ }^{3)}$ \\ ${ }^{1)}$ National Research Institute of Fisheries and Environment of Inland Sea, \\ Fisheries Research Agency \\ (2-17-5 Maruishi, Ohno, Saeki, Hiroshima 739-0452) \\ 2) Japan Sea National Fisheries Research Institute, Fisheries Research Agency \\ (1-5939-22 Suidocho, Niigata 951-8121) \\ ${ }^{3)}$ Kagoshima University, Faculty of Fisheries, Education and Research Center \\ for Marine Resources and Environment \\ (4-50-20 Shimoarata, Kagoshima 890-0056)
}

[Received December 17, 2001]

\begin{abstract}
Summary
Concentrations of tributyltin (TBT) and triphenyltin (TPT) compounds were determined in seawater, bottom sediments and fish and shellfish at various trophic levels in the marine benthic food web collected in Japan Sea to clarify the difference in the bioaccumulation pattern between TBT and TPT in the deep sea ecosystem. TBT was detected in all samples: 0.3 $0.8 \mathrm{ng} / \ell$ for the seawater, $4.4 \sim 16 \mathrm{ng} / \mathrm{g}$-dry for the sediment and $1.8 \sim 240 \mathrm{ng} / \mathrm{g}$-dry for various kinds of organisms. This deep seawater concentration is lower than the coastal water concentrations. Concentration of TPT in seawater was less than our detection limit $(0.9 \mathrm{ng} / \ell)$, but it was $3.9 \sim 12 \mathrm{ng} / \mathrm{g}$-dry for the sediment and $5.0 \sim 460 \mathrm{ng} / \mathrm{g}$-dry for the organisms. TPT concentrations of the sediments and organisms were similar to those reported in Tokyo Bay in 1999. TPT concentration becomes higher as the trophic level increases, suggesting the bioaccumulation of TPT through the food web. However, no such trend was observed for TBT. The higher TPT concentration in the benthic organisms than in the sediments implies that TPT can be transferred to benthic organisms from bottom sediments and that the sediments
\end{abstract}


can act as a secondary contamination source of TPT.

Key words: Bioaccumulation, organotin compounds, food web developed in the deep water, Japan Sea

\section{1. はじめに}

魚類などの水生生物はそれらが生息する水域の有害物 質を主として $2 つ の$ 経路で体内に取り込み蓄積する。す なわち, 海水に溶存する有害物質を呼吸器官の鰓を通し て取り込む経路（経鰓濃縮）と慨として摂取した生物に 蓄積された有害物質を消化管から取り込む経路（経口濃 縮）である。経口濃縮は飭生物（被食生物：prey）から 捕食生物（predator）への有害物質の移行である。ポリ 塩化ビフェニル（PCBs）のように残留性の高い有害物 質は海洋の食物網を通して栄養段階の高い生物に生物濃 縮されることが良く知られている”。したがって，自然 界の水生生物中有害物質濃度を単に実験的に求めた経鰓 濃縮の指標である生物濃縮係数（BCF）で評価すること は必ずしも十分ではなく，海洋食物網を通した有害物質 の生物濃縮過程を解析することは重要な課題である。有 機スズ化合物の食物網を通した生物濃縮過程は, トリブ チルスズ（以下 TBT と略す）化合物についてオランダ

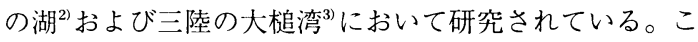
れらの研究により, TBT 化合物は食物網を通して高次 栄養段階生物に生物濃縮されない傾向が認められてい る。もう一つの代表的な有機スズ化合物, トリフェニル スズ (以下 TPT と略す) 化合物の食物網を通した生物濃 縮は淡水湖で研究されているにすぎなく ${ }^{2)}$, 海洋食物網 におけるTPT の生物濃縮についてはほとんど研究され ていない。したがって，日本海沖合域底層において漁獲 される魚介類を対象として対象水域の食物連鎖構造を明 らかにするとともに，食物網を通したTBT およびTPT 化合物の生物濃縮の差異を明らかにすることが本研究の 目的の一つである。

海洋に流入した踈水性の有害物質は，一般的に懸濁物 に吸着しやすく，最終的には底泥に堆積する舴す的。した がって, 過去に排出された多くの残留性有害物質は底泥 に残留し, その結果底泥の有害物質濃度は底層水に比較 して著しく高い。有機スズ化合物も例外でなく, 油壶湾 の調查では, 底泥中 TBT 濃度は海水中濃度の300 50,000 倍であり, 底泥の有機物濃度が高い水域，すなわ ち微細粒子の沈降・堆積しゃすい水域で底泥の TBT 濃 度が高いことが報告されている゙。

有機スズ化合物は，沿岸の浅海のみならず駿河湾の底

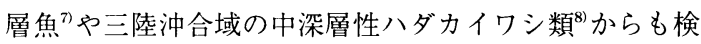
出され, 海洋に流入した有機スズ化合物が沖合域の底層 にも分布することが報告されている。すなわち, 海水中
有機スズ化合物濃度が低い沖合域の底層環境では，底泥 に堆積した有機スズ化合物が主要な污染源であると考え られる。

底泥に堆積した有機スズ化合物の挙動は必ずしも解明 されていない。その一部分は底層水に再溶出し, 水域生 態系を通して再循環し, 各種の水生生物に有害な影響を 及ほす可能性が示唆されているが9，その詳細について は明らかでない。一方，底泥に生息する底生生物，特に 多毛類に代表される表在性堆積物食者は底泥表面の有機 物を慨として摄取し，摂餌の際に底泥粒子も摂取するの で10), 底泥に堆積した有機スズ化合物は底層水へ再溶出 することなく, 底泥の固相および間隙水中の有機スズ化 合物が直接底生生物に移行し, さらには底泥を巡る食物 網を通して再循環する可能性が考えられる。したがっ て, 底泥を巡る食物網を構成する各種栄養段階の魚介類 中有機スズ化合物濃度を把握することにより有機スズ化 合物の底泥から底層の生物への移行・蓄積を解明するこ とが本研究のもう一つの目的である。

\section{2. 試料と方法}

\section{1 試料の採集}

\section{1.1 魚介類の採集}

Fig. 1に示す日本海山陰沖合域および大和堆において 1998年と1999年の 8 月 $~ 9$ 月に調查船による調査を行っ た。底生魚類, 甲殼類およびイカ類等の魚介類を底びき 網で採集した。有機スズ化合物分析用試料は $-20^{\circ} \mathrm{C} て ゙$ 凍 結保存した。生物種間の捕食・被食の関係を解析するた めに, 魚類, 甲款類および頭足類等の魚介類を船上で $10 \%$ 海水ホルマリンで固定して保存した。

\section{1.2 海水および底泥の採集}

底泥はスミスマッキンタイヤー型採泥器を用いて大和 堆 (St. 1), 阿賀野川沖合水域（St. 2) および若狭湾口 (St. 3) で採集した。阿賀野川沖合水域（St. 2）の水深 $115 \mathrm{~m}$ および大和堆（St. 1）の水深 $350 \sim 400 \mathrm{~m}$ の底層水 をバンドーン型採水器で採集した。底泥試料は一 $-20^{\circ} \mathrm{C}$ で, また, 海水は6 $\mathrm{N} \mathrm{HCl}$ を添加 $(1 \mathrm{~m} \ell / \ell)$ し, 酸性条 件下, 冷暗所で分析時まで保存した。

\section{2 胃内容物の生物種の查定}

ホルマリン固定により保存した魚介類から各生物種に ついて30個体を無作為に選定した。それらの胃を摘出 し, 胃内容物に見られる生物種を実体顕微鏡下で観察し た。内容物の餌生物は, 魚類およびエビ類は種に, 小型 


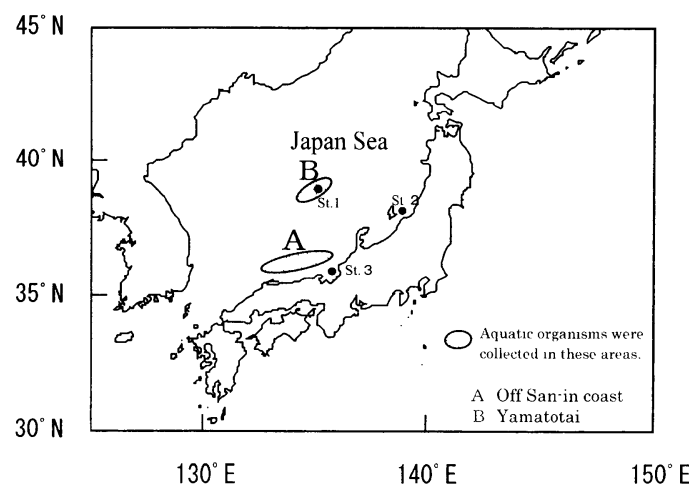

Fig. 1 The map showing the location of sampling stations of seawater, sediments and organisms

甲殼類はオキアミ類，端脚類，かいあし類に分類した。 その他の餌生物は多毛類, クモヒトデ類および貝類に区 分し, 泥状の粉砕物はデトリタスとして示した。結果は 調査個体数 (30個体) に対する飭生物が出現した個体数 の割合，すなわち，出現頻度（\%）として示した。これ らの結果から採集された魚介類の栄養段階を明らかにす るとともに食物連鎖構造を推定した。

\section{3 有機スズ化合物分析方法}

\section{3.1 海水中の TBT および TPT}

St. 1およびSt. 2で採集した海水試料をそれぞれ 2 検 体ずつ，ろ過などの処理を行わず直接分析に供した。海 水試料の分析は, Harino ら ${ }^{11} に$ 準拠して行った。すなわ ち, $10 \ell$ の海水試料に内部標準物質として塩化トリペン チルスズ (tripentyltin chloride (Ardrich 製，純度96\%)) $100 \mu \mathrm{g} / \ell$ を $2 \mathrm{~m} \ell$ 添加し, $400 \mathrm{~g}$ の $\mathrm{NaCl}$ および50m $12 \mathrm{NHCl}$ を加え, $200 \mathrm{~m} \ell$ の $0.1 \%$ トロポロン含有ベンゼン で30分間，3回かく找抽出した。得られたベンゼン抽出 液を無水硫酸ナトリウムで脱水後, $5 \mathrm{~m} \ell$ まで濃縮し た。これに $n$-プロピルマグネシウムブロミド（東京化成 製， $2 \mathrm{~mol} \mathrm{THF}$ 溶液） $1 \mathrm{~m} \ell$ を加え，30分間， $40^{\circ} \mathrm{C}$ の恒 温槽中でプロピル誘導体化を行った。プロピル化後,

$1 \mathrm{~N}$ 硫酸 $10 \mathrm{~m} \ell$ を滴下して過剩の $n$-プロピルマグネシウ ムブロミドを分解した。これにメタノール $10 \mathrm{~m} \ell$, 蒸留 水 $40 \mathrm{~m} \ell$ を加えて10分間振とう抽出し, 有機層を分離し

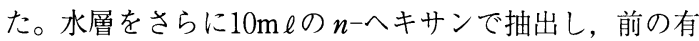
機層と合わせ, $0.2 \mathrm{~m} \ell$ まで濃縮して溶媒（ベンゼンおよ びnーヘキサン)を除去したのち， $n$-ヘキサンにより $5 \mathrm{~m} \ell$ として, フロリジルカラムクロマトグラフィーで精製し た。フロリジルカラムから溶離した $n$ ーヘキサン溶液を $0.1 \mathrm{~m} \ell$ に濃縮・定容し，ガスクロマトグラフィー用試料 とした。キャピラリーカラム (Hewlett-Packard 製,
Ultra-1）を備えた FPD 検出器付ガスクロマトグラフ (GC-FPD（島津製, Shimadzu GC-15A)）を用いて分離 し, 塩化トリペンチルスズを標準物質とする内部標準法 により試料の TBT およびTPTを定量した。なお, 装置 の最小検出量と前処理過程での濃縮倍率から求められる 本分析法の理論検出限界はTBTで $0.3 \mathrm{ng} / \ell$, TPT で $0.9 \mathrm{ng} / \ell$ であった。添加したTBT およびTPT の回収率 は, $10 \mathrm{ng} / \ell$ の濃度で $90 \%$ あったた。

\section{3.2 底泥および生物中 TBT および TPT}

St. 1, St. 2およびSt. 3で採集した底泥試料をそれぞ れ遠心分離して間隙水を除去したのち，2検体ずつを分 析に供した。生物試料のうち，ズワイガニについては殼 を除いた軟体部を分析に供した。残りの生物試料のう ち, $10 \mathrm{~g}$ 以上の生物については 1 個体を丸ごとホモジナ イズし，その一部を分析に供した。クモヒトデ，エビ 類, キュウリエソなど $10 \mathrm{~g}$ に満たない生物については複 数個体を合わせて 1 検体とし，分析に供した。底泥およ び生物試料の分析は, 高見ら ${ }^{12}$ の方法に準拠して行っ た。すなわち, $10 \mathrm{~g}$ の底泥および生物試料に内部標準物 質の塩化トリペンチルスズを $1 \mu \mathrm{g}$ (塩化トリペンチル スズ溶液 $(10 \mathrm{mg} / \ell)$ を $100 \mu \ell)$ 添加し, $100 \mathrm{~m} \ell$ の $1 \mathrm{~N}$ 塩 酸メ夕ノール：酢酸エチル混液 $(1: 1, \mathrm{v} / \mathrm{v})$ でホモジ ナイズ抽出した。これを遠心分離して得られた上清に $100 \mathrm{~m} \ell$ の $10 \% \mathrm{NaCl}$ 溶液を加え, $25 \mathrm{~m} \ell$ の酢酸エチル $: n-$ ヘキサン混夜（3:2, v/v）で 2 回抽出した。合わせた 抽出液に $100 \mathrm{~m} \ell$ の $n$-ヘキサンを加えて 1 時間放置した のち, 無水硫酸ナトリウムで脱水した。これを $0.2 \mathrm{~m} \ell ま$ で濃縮したのちエ夕ノールに溶解し, 陰・陽イオン交換 樹脂カラムを通して精製した。イオン交換樹脂で精製し たTBT および TPT を海水試料と同様にプロピルマグネ シウムブロミドを用いてプロピル誘導体とし，プロピル 誘導体を抽出・濃縮したのち, フロリジルカラムを用い て精製した。この精製物を $0.2 \mathrm{~m} \ell$ に濃縮・定容して GCFPD 用試料とした。海水試料と同様に内部標準法により 試料中の TBT および TPTを定量した。生物試料の場合 の本分析法の理論検出限界は TBT で1. 0ng/g 湿重, TPT で3.0ng/g 湿重であった。本法の回収率は, $0.6 \mu \mathrm{g} / \mathrm{g}$ 湿重

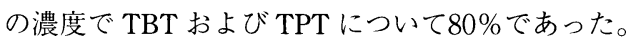

\section{3. 結果および考察}

\section{1 底生生物群集の食物連鎖構造}

3. 1.1 山陰沖合域

底びき網により漁獲された魚介類の優占種は, 甲殼類 ではズワイガニ, ホッコクアカエビ, トゲザコエビ, ハ サミモエビの 4 種, 魚類ではアカガレイ, ヒレグロ，八 タハ夕，ノロゲンゲ，タナカゲンゲ，セッパリカジカ, アゴゲンゲの 7 種で合計11種であった。

これらの優占種11種について，それぞれ30個体の胃内 
容物を分析し, 飭生物の出現頻度を Table 1に示した。 餌生物の出現頻度から主要種の食性を推定すると, 魚類 を多く摂食をしているのは夕ナカゲンゲとアゴゲンゲで あった。タナカゲンゲはヒレグロやアカガレイの幼魚 を，また，アゴゲンゲはアカガレイを摂食していた。夕 ナカゲンゲは魚類の他にイカ類およびカニ・エビ類を筫 食しており，漁獲された生物種の中では最も栄養段階の 高い生物であると推定される。アカガレイはクモヒト デ，小型のエビ類および多毛類などの多様な飭生物を摂 食しており，また，八タハ夕，ノロゲンゲ，七ッパリカ ジカは主として端脚類を摂食していた。ズワイガニおよ びホッコクアカエビは端脚類などの小型のエビ類を主に 摂食するが，多毛類等も摂食していた。トゲザコエビは 小型のエビ類の他にクモヒトデや貝類などの底生生物な らびにいわゆるデトリタスといわれる底泥の有機物を摂 食していた。ハサミモエビは主としてデトリタスを摂食 していると考えられる。
食物連鎖構造を推定するために，以下の基準で漁獲物 の栄養段階を分類した。

栄養段階 1：主としてデトリタスを攝食

栄養段階 2 : 多毛類, 端脚類, オキアミ類およびクモ ヒトデ類を摂食

栄養段階 3 : 魚類, エビ・カ二類およびイカ類を摂食 この分類に準拠すると, 最も栄養段階の低い栄養段階 1 には，ハサミモエビ，トゲザコエビおよびホッコクアカ エビが，栄養段階 2 にはズワイガニ，八タハ夕，ノロゲ ンゲおよびヒレグロが，また，最も栄養段階の高い栄養 段階 3 には夕ナカゲンゲ，アゴゲンゲ，アカガレイおよ びセッパリカジカが分類された。それぞれの魚介類の栄 養段階に基づけば，山陰沖合水域の底層には Fig. 2に示 した食物連鎖構造が形成されると推察される。

\section{1.2 大和堆}

底びき網を用いて採集された漁獲物のうち, 甲款類で はホッコクアカエビ, トゲザコエビ, アシナガイバラモ

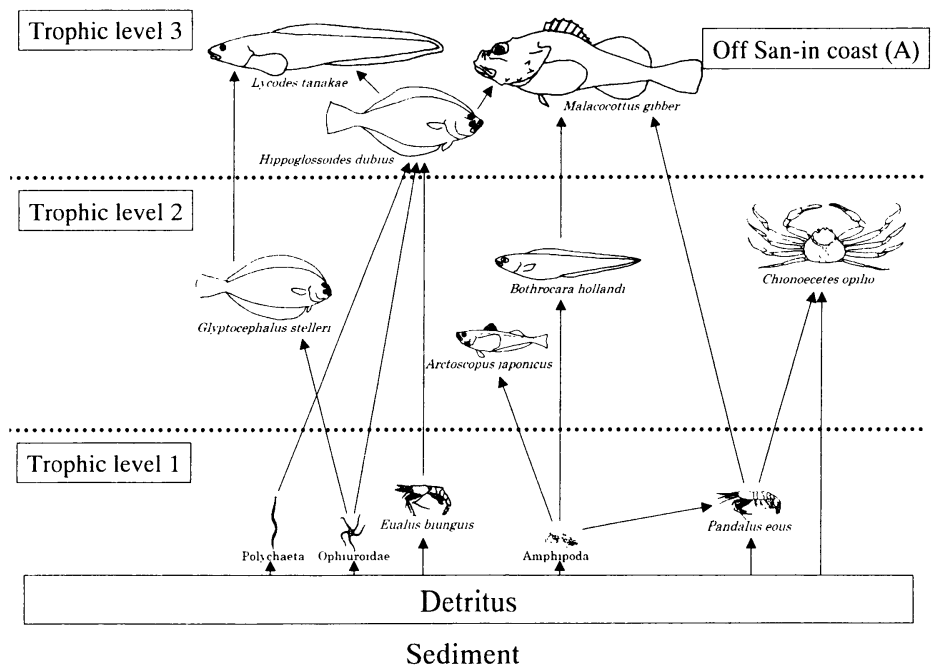

Fig. 2 The food chain structure developed in the deep water of off San-in coast (A)

Table 1 Frequency in appearance of prey in the stomac of predator collected at waters off San-in coast (A) in Japan Sea

\begin{tabular}{|c|c|c|c|c|c|c|c|c|c|c|}
\hline \multicolumn{2}{|r|}{ Predator } & \multicolumn{9}{|c|}{ Frequency in appearance of prey in the stomac of predator $(\%)^{*}$} \\
\hline $\begin{array}{l}\text { Japanese } \\
\text { common name }\end{array}$ & Scientific name & Fish & Squid & Decapoda & Amphipoda & Euphausiacea & Polychaeta & Ophiuroidae & Shellfish & Detritus \\
\hline Tanakagenge & Lycodes tanakae & 26.7 & 23.3 & 26.7 & 26.7 & & & & 16.6 & \\
\hline Agogenge & Petroschmidtia toyamensts & 16.7 & 3.3 & 16.7 & 6.7 & 3.3 & 13.3 & 6.7 & 50.0 & \\
\hline Sepparikajika & Malacocottus gibber & 6.7 & 6.7 & 30.0 & 50.0 & 16.7 & 6.7 & 3.3 & 26.7 & \\
\hline Akagarei & Hippoglossoides dubius & 6.7 & 33.3 & 13.3 & 3.3 & 16.7 & & & 3.3 & \\
\hline Hireguro & Glvptocephalus stelleri & & & & 6.7 & & 50.0 & 23.3 & 6.7 & \\
\hline Norogenge & Bothrocara hollandi & & & 16.7 & 66.7 & 6.7 & 3.3 & 3.3 & & \\
\hline Hatahata & Arctoscopus japonicus & & & & 86.7 & 13.3 & & & & \\
\hline Zuwaigani & Chionoecetes opilio & & & 13.3 & 13.3 & & 3.3 & 3.3 & 3.3 & \\
\hline Hokkokuakaebi & Pandalus eous & & & 13.3 & 16.7 & & 16.7 & 6.7 & 6.7 & 100.0 \\
\hline Togezakoebi & Argis toyamaensis & & & 3.3 & 13.3 & & & 3.3 & 16.7 & 100.0 \\
\hline Hasamimoebi & Eualus bunnguis & & & & & & & & 6.7 & 100.0 \\
\hline
\end{tabular}

*1: (number of predator ingesting the prey / total number of predators examined $(30$ individuals $)) \times 100$ 
エビ, ズワイガニの 4 種, 魚類ではノロゲンゲ, セッパ リカジカ, ヒレグロ, アカガレイ, ザラビクニン, ウロ コメガレイ, ハタハタ, ドブカスベの 8 種, 頭足類では ドスイカおよびホタルイカモドキの 2 種が優占種であ り，これらの生物が底層の食物連鎖の骨格を形成してい ると考えられる。

山陰沖合域の調査と同様に, 底生魚介類の主要 14 種を 対象として，それぞれ30個体の胃内容物を分析した。 Table 2に示した飭生物の出現頻度から食性を推定する と, 魚類を多量に摂食しているのは, ドスイカ, ドブカ スベ, セッパリカジカであった。ドスイカは小型魚類の キュウリエソを摂食していた。イカ類は飭生物を摂取す る際に歯で破砕することおよびイカ類は共食いをするこ と等からその栄養段階は高く ${ }^{13)}$, ドスイカの胃内容物に 認められたデトリタスは底泥表面の有機物ではなく, 餌 生物の破砕物であると考えられる。ドブカスベは魚類 (ノロゲンゲが多く, 他にザラビクニン , ヒレグロなど)
の他にエビ類（トゲザコエビが多く，他にハサミモエ ビ, アシナガイバラモエビ，ホッコクアカエビなど), ズワイガニ, ドスイカ，端脚類およびオキアミ類を，ま た，セッパリカジカは魚類の他に端脚類，才キアミ類お よび多毛類を摂取していた。ノロゲンゲもこれらの魚類 と同様な飭生物の構成を示し, 同様な食性であった。力 レイ類の 3 種では，それぞれ主要な慨生物が異なってお り, アカガレイは主としてクモヒトデ類を, ヒレグロは 多毛類とクモヒトデ類を, ウロコメガレイは端脚類とオ キアミ類を摂食していた。ザラビクニンやハ夕ハ夕，ホ タルイカモドキは端脚類を主要な飭としていた。ホッコ クアカエビ, トゲザコエビ, アシナガイバラモエビ, ズ ワイガニでは, 端脚類および多毛類の消化物が認められ るが, 消化が進んでいるために, その生物種は不明で あった。餌生物の種類と出現頻度は山陰沖合で漁獲され た魚介類のそれと類似していた。

山陰沖合の食物連鎖構造の推定において用いた同じ基

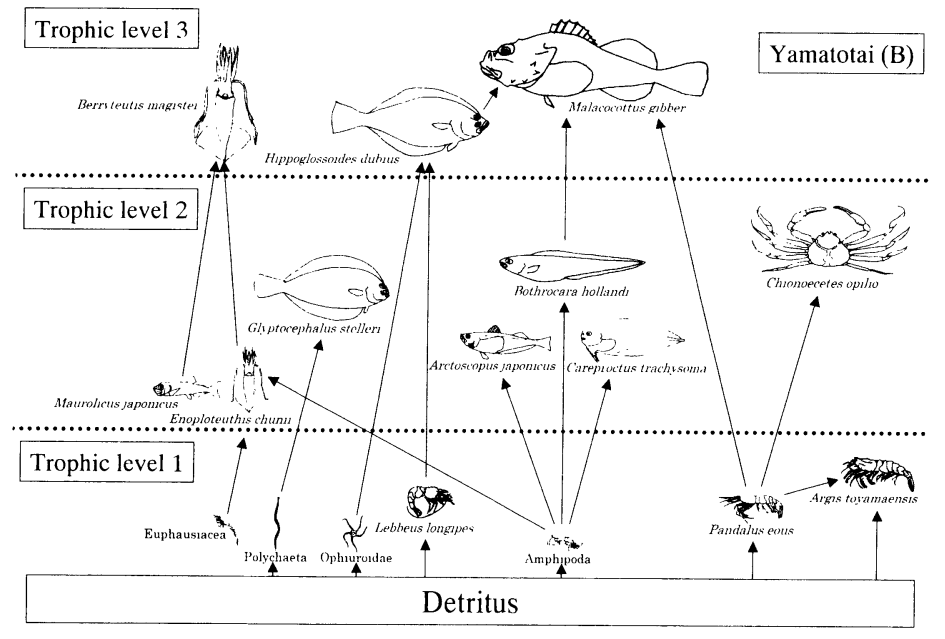

Sediment

Fig. 3 The food chain structure developed in the deep water of Yamatotai (B)

Table 2 Frequency in appearance of prey in the stomac of predator collected at Yamatotai (B) in Japan Sea

\begin{tabular}{|c|c|c|c|c|c|c|c|c|c|c|}
\hline \multicolumn{2}{|c|}{ Predator } & \multicolumn{9}{|c|}{ Frequency in appearance of prey in the stomac of predator $(\xi))^{.1}$} \\
\hline $\begin{array}{l}\text { Japanese } \\
\text { common name }\end{array}$ & Scientific name & Fish & Squid & Decapoda & Amphipoda & Euphausiacea & Polychaeta & Ophiuroidae & Shellfish & Detritus \\
\hline Sepparikajika & Malacocottus gibber & 10.0 & 6.6 & 40.0 & 56.6 & 33.3 & 13.3 & 3.3 & 10.0 & \\
\hline Norogenge & Bothrocara hollandi & 66 & & 16.6 & 76.6 & 13.3 & 3.3 & 3.3 & & \\
\hline Dobukasube & Bathuraja smirnovi & 13.3 & 16.6 & 26.6 & 93.3 & 13.3 & & & & \\
\hline Akagarei & Hippoglossoides dubius & 6.6 & 3.3 & 16.6 & 3.3 & 3.3 & 3.3 & 86.6 & 3.3 & \\
\hline Hireguro & Glyptocephalus stelleri & 3.3 & & & 3.3 & & 50.0 & 23.3 & & \\
\hline Urokomegarei & Acanthopsetta nadeshnyi & 6.6 & 6.6 & 13.3 & 63.3 & 23.3 & & 3.3 & 6.6 & \\
\hline Zarabikunin & Careproctus trachysoma & & & 6.6 & 93.3 & 66.6 & & & & \\
\hline $\begin{array}{l}\text { Hatahata } \\
\text { Dosuika }\end{array}$ & $\begin{array}{l}\text { Arctoscopus japonicus } \\
\text { Berryteutts magister }\end{array}$ & 300 & & & 90.0 & 10.0 & & & & 500 \\
\hline Hotaruikamodoki & Enoploteuthis chunii & 30.0 & 16.6 & 6.6 & $\begin{array}{l}40.0 \\
73.3\end{array}$ & $\begin{array}{l}10.0 \\
40.0\end{array}$ & & & & 50.0 \\
\hline Hokkokuakaebi & Pandalus eous & & & 3.3 & 3.3 & & 13.3 & 6.6 & 6.6 & 100.0 \\
\hline Togezakoebi & Argis toyamaensis & & & 33 & 10.0 & & & 3.3 & 10.0 & 100.0 \\
\hline Ashinagaibaramoebi & Lebbeus longipes & & & & & & & & 6.6 & 100.0 \\
\hline Zuwaigani & Chionoecetes opilio & & & 33 & 13.3 & & 3.3 & 3.3 & 3.3 & 100.0 \\
\hline
\end{tabular}

*1: (number of predator ingesting the prey / total number of predators examined ( 30 individuals $)) \times 100$ 
準で魚介類の栄養段階を適用すると, クモヒトデ, アシ ナガイバラモエビ, ホッコクアカエビ, トゲザコエビお よび端脚類が栄養段階 1 に，ヒレグロ，キュウリエソお よびズワイガニが栄養段階 2 に，また，ドスイカ，アゴ ゲンゲ, アカガレイおよびセッパリカジカが栄養段階 3 に分類された。対象生物の栄養段階をまとめると大和堆 底層の食物連鎖は Fig. 3に示した構造であると考えられ る。

\section{2 対象水域の海水および底泥中有機スズ化合物濃 度}

St. 1およびSt. 2で採集された底層海水の TBT 濃度は Table 3に示したように，それぞれ，0.6〜0.8ng/ $\ell$ おび $0.3 \sim 0.6 \mathrm{ng} / \ell$ であり, 阿賀野川沖合水域に比較して大和 堆でやや高い傾向であった。また, 海水中 TPT濃度はい ずれの水域においても検出限界 $(0.9 \mathrm{ng} / \ell)$ 以下であっ た。

外洋水の有機スズ化合物濃度を測定した研究結果はそ しいが, 水深 $50 \mathrm{~m}$ 層の海水中 TBT 濃度は日本海大和堆 で1. $0 \sim 1.8 \mathrm{ng} / \ell$, 北西太平洋北海道沖合水域で1.0 $1.6 \mathrm{ng} / \ell$ であった ${ }^{14)}$ 。一方, 田尾ら ${ }^{15)}$ は東シナ海における 海水中 TBT の鉛直分布を研究し, 海水中 TBT 濃度が鉛 直的に大きく変動しないことを明らかにした。また，い ずれの研究においても, 沖合域の海水から TPT は検出 されなかった。したがって, 本研究で測定した底層海水 の TBT および TPT 濃度は既往の文献值と概ね一致する ことが明らかであった。

底泥中の TBT 濃度（括弧内は湿重量ベース平均値） は, Table 3に示したように, St. 2で4.4〜 5.6ng/g 乾重 (3. $4 \mathrm{ng} / \mathrm{g})$, St. 3 で5.9 8.3ng/g 乾重 $(3.3 \mathrm{ng} / \mathrm{g})$ および St. 1で5.6〜 16ng/g 乾重 (7.3ng/g) であった。大和堆の 底泥中 TBT 濃度は阿賀野川沖合水域あるいは若狭湾口 に比べ, 差はなかった。底泥中の TBT 濃度は底層水中 の濃度に比較して阿賀野川沖合水域で7, 000 20, 000倍, 大和堆で7, 500～26,000倍高かった。すなわち, 海水中 濃度が低い日本海底層においては, 底泥に堆積する有機
スズ化合物が主要な污染源となることが考えられる。 海水中の TPT 濃度は検出限界 $(0.9 \mathrm{ng} / \ell)$ 以下であっ たが, 底泥には検出され, St. 2, St. 3および St. 1にお ける濃度（括弧内は湿重量ベース平均值）は，それぞ れ, $5.9 \sim 7.4 \mathrm{ng} / \mathrm{g}$ 乾重 $(4.5 \mathrm{ng} / \mathrm{g}), 6.1 \sim 12 \mathrm{ng} / \mathrm{g}$ 乾重 $(4.2$ $\mathrm{ng} / \mathrm{g})$ および3.9 6.7ng/g 乾重 $(3.6 \mathrm{ng} / \mathrm{g})$ であり, 地点 間の差は明確でなかった。沖合水域底泥の TBT 濃度は 東京湾底泥の濃度（1999年の調査では47～300ng/g 乾重） 16)に比較すると低いが，TPT 濃度は東京湾底泥における 濃度（1999年の調查では1.3〜 15ng/g 乾重）とほほ同レ ベルであった。海域に流入した有機スズ化合物が懸濁物 質への吸着等の過程を通して沖合水域の深層に移行 · 拡 散していることが明らかであった。

\section{3 魚介類中有機スズ化合物濃度}

\section{3. 1 TBT 濃度}

底層の食物連鎖における栄養段階 1 の生物中 TBT 濃 度（括弧内は検体数および湿重量べース平均値）は, 大 和堆のクモヒトデ:8.8 12ng/g 乾重 ( $\mathrm{n}=2 ; 5.6 \mathrm{ng} / \mathrm{g})$, ハサミモエビ : 59 63ng/g 乾重 $(\mathrm{n}=2 ; 16 \mathrm{ng} / \mathrm{g})$, ホッ コクアカエビ : $49 \pm 13 \mathrm{ng} / \mathrm{g}$ 乾重 $(\mathrm{n}=5 ; 11 \mathrm{ng} / \mathrm{g})$, トゲ ザコエビ: $5.1 \pm 2.1 \mathrm{ng} / \mathrm{g}$ 乾重 $(\mathrm{n}=8 ; 1.5 \mathrm{ng} / \mathrm{g})$ に比べ, 山陰沖合水域のクモヒトデ : 4.6ng/g 乾重 $(\mathrm{n}=1$; $2.5 \mathrm{ng} / \mathrm{g})$, ハサミモエビ: $120 \mathrm{ng} / \mathrm{g}$ 乾重 $(\mathrm{n}=2 ; 34 \mathrm{ng} / \mathrm{g})$, ホッコクアカエビ : $61 \pm 15 \mathrm{ng} / \mathrm{g}$ 乾重 $(\mathrm{n}=6 ; 16 \mathrm{ng} / \mathrm{g})$, トゲザコエビ : 13～16ng/g（n=2；3.9ng/g）で高かっ た。また, 栄養段階 2 および 3 の生物中 TBT 濃度（括弧 内は検体数および湿重量ベース平均值) は, 大和堆のノ ロゲンゲ : $8.0 \pm 4.3 \mathrm{ng} / \mathrm{g}$ 乾重 $(\mathrm{n}=5 ; 1.6 \mathrm{ng} / \mathrm{g})$, 八夕 ハ夕: $170 \pm 30 \mathrm{ng} / \mathrm{g}$ 乾重 $(\mathrm{n}=3 ; 42 \mathrm{ng} / \mathrm{g})$, ヒレグロ: $18 \pm 9 \mathrm{ng} / \mathrm{g}$ 乾重 $(\mathrm{n}=4 ; 3 . \mathrm{ng} / \mathrm{g})$, ズワイガニ $: 1.8$ $5.3 \mathrm{ng} / \mathrm{g}$ 乾重 $(\mathrm{n}=2 ; 1.0 \mathrm{ng} / \mathrm{g})$, アカガレイ $: 4.4$ $4.7 \mathrm{ng} / \mathrm{g}$ 乾重 $(\mathrm{n}=2 ; 1.1 \mathrm{ng} / \mathrm{g})$ に比べ, 山㓌沖合水域の ノロゲンゲ : $22 \pm 19 \mathrm{ng} / \mathrm{g}$ 乾重 $(\mathrm{n}=4 ; 3.6 \mathrm{ng} / \mathrm{g})$, 八夕 ハ夕: $170 \sim 240 \mathrm{ng} / \mathrm{g}$ 乾重 $(\mathrm{n}=2 ; 60 \mathrm{ng} / \mathrm{g})$, ヒレグロ $31 \mathrm{ng} / \mathrm{g}$ 乾重 $(\mathrm{n}=2 ; 5.9 \mathrm{ng} / \mathrm{g})$, ズワイガニ: $8.5 \pm$

Table 3 TBT and TPT concentration in seawater of bottom layer and sediment at stations in Japan Sea

\begin{tabular}{|c|c|c|c|c|c|c|}
\hline & \multicolumn{3}{|c|}{ TBT } & \multicolumn{3}{|c|}{ TPT } \\
\hline & St. 1 & St. 2 & St. 3 & St. 1 & St. 2 & St. 3 \\
\hline Seawater $^{* 1} \quad(\mathrm{ng} / \mathrm{L})$ & $0.6-0.8$ & $0.3-0.6$ & $\mathrm{NA}^{* 2}$ & $<0.9$ & $<0.9$ & NA \\
\hline Sediment $^{* 1}(\mathrm{ng} / \mathrm{g}-\mathrm{dry})$ & $5.6-16$ & $4.4-5.6$ & $5.9-8.3$ & $3.9-6.7$ & $5.9-7.4$ & $6.1-12$ \\
\hline
\end{tabular}


$8.8 \mathrm{ng} / \mathrm{g}$ 乾重 $(\mathrm{n}=14 ; 1.8 \mathrm{ng} / \mathrm{g})$, アカガレイ $: 15 \pm 27 \mathrm{ng} / \mathrm{g}$ 乾重 $(\mathrm{n}=10 ; 3.7 \mathrm{ng} / \mathrm{g})$ で栄養段階 1 の生物と同様に高 かった。山陰沖合および大和堆のいずれの水域において も栄養段階 2 および 3 の生物中 TBT 濃度は, 栄養段階 1 の生物中 TBT 濃度に比較して同等か, やや低い傾向 であった。しかし, ハタハ夕の TBT 濃度（170～240ng/g 乾重）は他の栄養段階 2 および 3 の生物に比較して著し く高かった。大和堆における他の栄養段階 1 の生物中 $\mathrm{TBT}$ 濃度（括弧内は検体数掞よび湿重量ベース平均值） は，アシナガイバラモエビ : 61 78ng/g 乾重（ $\mathrm{n}=2$; $19 \mathrm{ng} / \mathrm{g})$, 栄養段階 2 および 3 の生物中 TBT 濃度は, キュウリエソ : $63 \sim 66 \mathrm{ng} / \mathrm{g}$ 乾重 $(\mathrm{n}=2 ; 17 \mathrm{ng} / \mathrm{g})$ ，ドス イカ : $87 \pm 18 \mathrm{ng} / \mathrm{g}$ 乾重 $(\mathrm{n}=4 ; 27 \mathrm{ng} / \mathrm{g})$, アゴゲンゲ : $6.2 \sim 6.9 \mathrm{ng} / \mathrm{g}$ 乾重 $(\mathrm{n}=2 ; 1.1 \mathrm{ng} / \mathrm{g})$ ，セッパリカジカ： $29 \sim 82 \mathrm{ng} / \mathrm{g}$ 乾重 $(\mathrm{n}=2 ; 9.1 \mathrm{ng} / \mathrm{g})$, ドブカスベ: 60 $64 \mathrm{ng} / \mathrm{g}$ 乾重 $(\mathrm{n}=2 ; 8.0 \mathrm{ng} / \mathrm{g})$ であり，これらの魚介類 の TBT 濃度を Fig. 4および5に示した。

Takahashi らは駿河湾深海 $(220 \sim 980 \mathrm{~m})$ で漁獲した
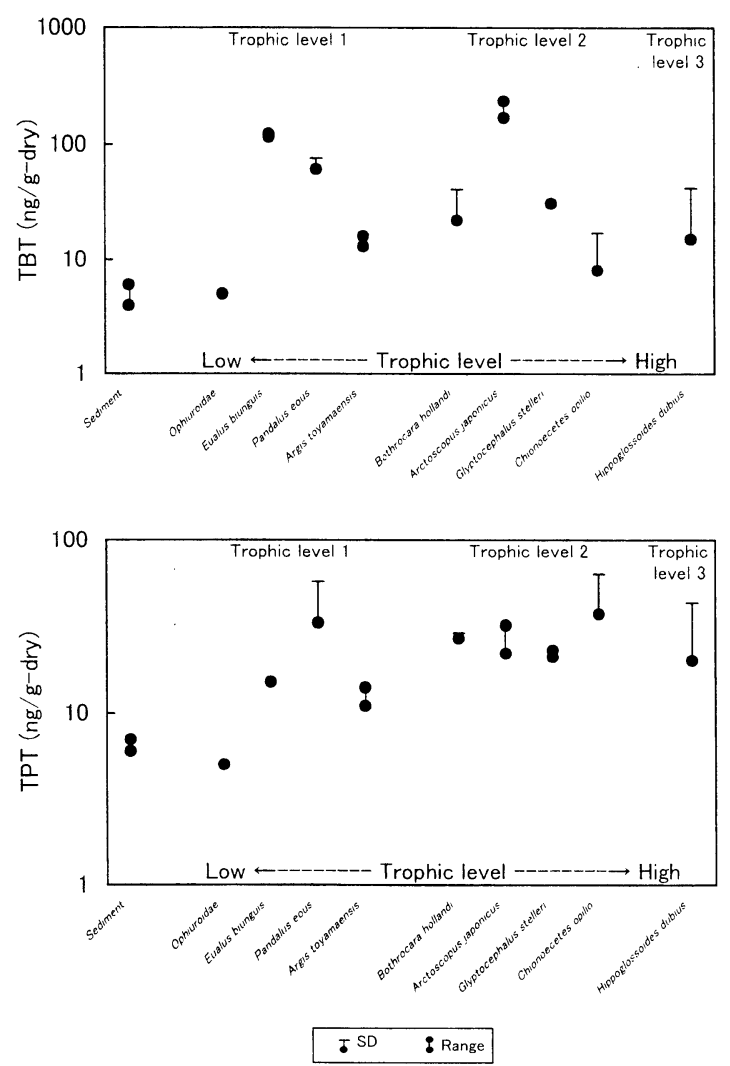

Fig. 4 Relationships between TBT and TPT concentration in organisms and their trophic level in food chain developed in the deep water of off San-in coast (A)
底層性魚類（8 種），甲殼類（ 9 種），棘皮動物（4 種） および腹足類（1 種）と同海域の表層で採集した表層性 魚類の（11種）のモノ，ジ拉よびトリブチルスズ化合物 の合計濃度（ $\Sigma \mathrm{BTS}$ ）を測定し, 駿河湾の表層と底層に おける濃度を比較した。 $\Sigma$ BTs 濃度は表層性魚類筋肉で 9.9 180ng/g 湿重, 底層性魚類筋肉で2.3 170 ng/g 湿重 であり，その濃度は表層と底層で大きな差のないことを 明らかにした。一方，三陸沖合水域に生息する中深層性 ハダカイワシ類の TBT 濃度は鉛直移動する種 $(<12.8$ $\sim 167 \mathrm{ng} / \mathrm{g}$ 乾重) に比べて移動しない種の TBT 濃度（< $13.9 \sim 22.4 \mathrm{ng} / \mathrm{g}$ 乾重）で低いことが報告されている8 日本海のハ夕ハ夕のように, TBT 濃度（170 240ng/g 乾 重）が北西太平洋のハダカイワシ類より高い魚類も認め られるが, 日本海底層魚介類の TBT 濃度は北西太平洋 の中深層性ハダカイワシ類と大きな差はないと考えられ る。

\section{3. 2 TPT 濃度}

山陰沖合水域および大和堆で採集された魚介類中の
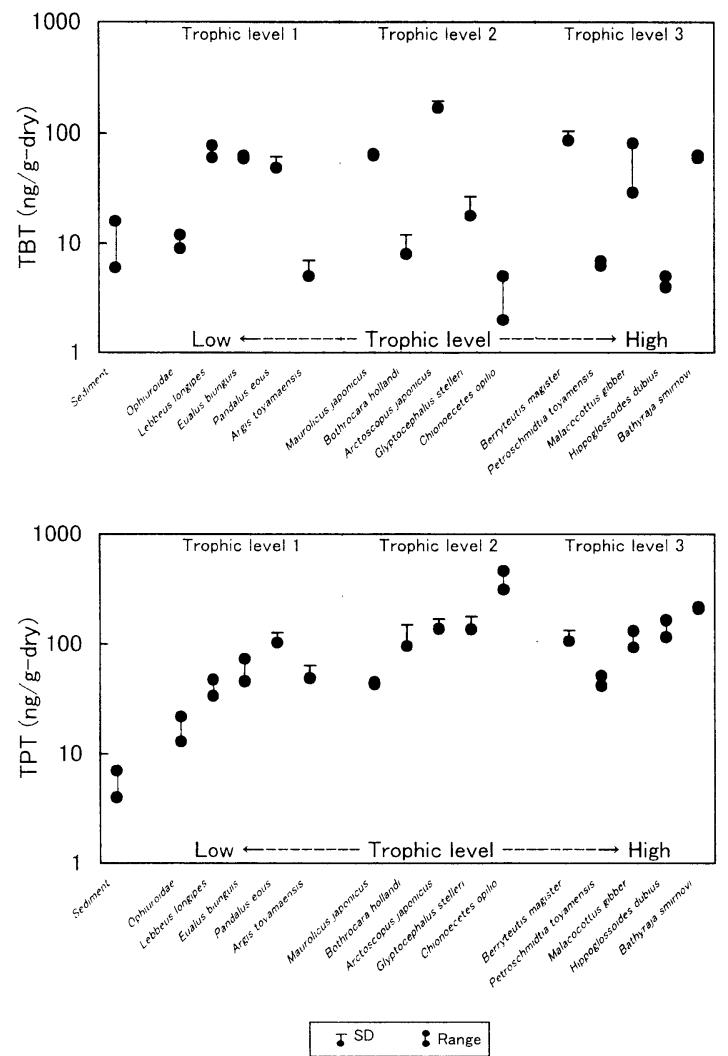

Fig. 5 Relationships between TBT and TPT concentration in organisms and their trophic level in food chain developed in the deep water of Yamatotai (B) 
TPT 濃度は，以下の通りであった（検体数はそれぞれ TBT の分析と同様)。大和堆底層の食物連鎖における栄 養段階 1 の生物中 TPT 濃度（括弧内は湿重量ベース平 均值）は，クモヒトデで13〜 $22 \mathrm{ng} / \mathrm{g}$ 乾重 $(9.5 \mathrm{ng} / \mathrm{g})$ ，八 サミモエビで46 73ng/g乾重 (15ng/g)，ホッコクアカエ ビで $100 \pm 20 \mathrm{ng} / \mathrm{g}$ 乾重 $(23 \mathrm{ng} / \mathrm{g})$ ，トゲザコエビで $49 \pm$ $14 \mathrm{ng} / \mathrm{g}$ 乾重 $(14 \mathrm{ng} / \mathrm{g})$ であり, 山陰沖合水域のクモヒト デ: $5.0 \mathrm{ng} / \mathrm{g}$ 乾重 $(2.7 \mathrm{ng} / \mathrm{g})$, ハサミモエビ: $15 \mathrm{ng} / \mathrm{g}$ 乾重 $(4.4 \mathrm{ng} / \mathrm{g})$, ホッコクアカエビ : $33 \pm 24 \mathrm{ng} / \mathrm{g}$ 乾重 $(8.5 \mathrm{ng} / \mathrm{g})$ ，トゲザコエビ: $11 \sim 14 \mathrm{ng} / \mathrm{g}$ 乾重 $(3.4 \mathrm{ng} / \mathrm{g})$ に 比べて高かった。一方, 大和堆の栄養段階 2 および 3 の 生物中 TPT 濃度（括弧内は湿重量ベース平均值）は，， ロゲンゲで $96 \pm 53 \mathrm{ng} / \mathrm{g}$ 乾重 $(16 \mathrm{ng} / \mathrm{g})$ ，ハ夕ハ夕で $140 \pm$ $30 \mathrm{ng} / \mathrm{g}$ 乾重 $(34 \mathrm{ng} / \mathrm{g})$ ，ヒレグロで $140 \pm 40 \mathrm{ng} / \mathrm{g}$ 乾重 (23ng/g), ズワイガニで310 460ng/g 乾重 $(72 \mathrm{ng} / \mathrm{g})$, ア カガレイで120～160ng/g 乾重 (34ng/g) であり，山陰沖 合水域のノロゲンゲ : $27 \pm 2 \mathrm{ng} / \mathrm{g}$ 乾重 $(4.6 \mathrm{ng} / \mathrm{g})$, 八夕 ハ夕:22 32ng/g 乾重 $(8.1 \mathrm{ng} / \mathrm{g})$ ，ヒレグロ:21 23ng/g 乾重 $(4.2 \mathrm{ng} / \mathrm{g})$ ，ズワイガニ：37 $26 \mathrm{ng} / \mathrm{g}$ 乾重 (8.1 $\mathrm{ng} / \mathrm{g})$, アカガレイ : $20 \pm 23 \mathrm{ng} / \mathrm{g}$ 乾重 $(4.9 \mathrm{ng} / \mathrm{g})$ に比べて 高かった。大和堆における他の栄養段階 1 の生物中 TPT 濃度（括弧内は湿重量ベース平均值）は, アシナガイバ ラモエビ：34〜 47ng/g 乾重 (11ng/g)，栄養段階 2 および 3 の生物中 TPT 濃度は, キュウリエソ: $43 \sim 45 \mathrm{ng} / \mathrm{g}$ 乾重 (11ng/g)，ドスイカ: $110 \pm 30 \mathrm{ng} / \mathrm{g}$ 乾重 $(33 \mathrm{ng} / \mathrm{g})$, アゴゲ ンゲ: 42 51ng/g 乾重 $(8.1 \mathrm{ng} / \mathrm{g})$ ，七ッパリカジカ:93 $130 \mathrm{ng} / \mathrm{g}$ 乾重 $(19 \mathrm{ng} / \mathrm{g})$ ，ドブカスベ : 210 220ng/g 乾重 (27ng/g) であり,これらの魚介類のTPT濃度を Fig. 4 お よび5に示した。これらの魚介類の TPT 濃度は東京湾の スズキで測定された濃度（1999年の調査で20ng/g 湿重以 下) ${ }^{16)}$ とほほ同レベルであると考えられ，沖合域底層の 底泥および魚介類中 TPT 濃度は沿岸域に匹敵すること が明らかとなった。

山陰沖合および大和堆のいずれの水域においても, 栄 養段階 2 および 3 の生物中 TPT 濃度は, 程度は小さい が，栄養段階 1 の生物に比べ高かった。すなわち，TPT は食物網を通して栄養段階 1 の生物から栄養段階 2 およ び 3 の生物へと濃縮される傾向が認められた。大和堆の 栄養段階 1 の生物中 TPT 濃度は山陰沖合水域に比較し て高い。したがって，栄養段階 2 および 3 の生物中濃度 も栄養段階 1 の生物中濃度を反映して山㓌沖合水域に比 較して大和堆で高いことが明らかとなった。

\section{4 有機スズ化合物の魚介類への蓄積経路の寄与}

海水中有害物質の水生生物の鰓を通した移行・蓄積の 程度は生物濃縮係数 (BCF) として評価される。飼育実 験から求めた TBT 化合物の BCF は海産魚類で3, 000 $9,400^{17)}$ ，クルマエビで5, 300 6, $000^{18)}$ が報告されてい
る。一方, TPT の BCF は海産魚類で $3,100 \sim 4,100^{17}$, ク ルマエビで $200^{18)}$ と報告されている。

大和堆底層水中の TBT 濃度の平均值 $(0.7 \mathrm{ng} / \ell)$, 飼 育実験で測定された TBT の BCF（海産魚類で5,000, ク ルマエビで 5,500$)$ および魚類および甲款類の水分（大 和堆の魚介類について測定した平均値で魚類および甲殻 類でそれぞれ $80 \%$ および74\%）を用いると，海水からの TBT の乾燥重量当たりの蓄積濃度は魚類で18ng/g 乾重, 甲款類で $15 \mathrm{ng} / \mathrm{g}$ 乾重と試算される。魚類が海水から濃縮 する濃度 (18ng/g 乾重) の大和堆で採集された魚類中蓄 積濃度に対する比はハ夕ハ夕の0.1からアカガレイの3.6 倍の範囲であり，両種を除くとその比は0.3〜2.6にな る。一方，エビ類に関する同様な比は，アシナガイバラ モエビの0.2からトゲザコエビの3.0の範囲である。すな わち, 大和堆で採集された魚類およびエビ類中の TBT 濃度に対しては, 海水から鰓を通した経路の寄与が後述 する TPTに比べ大きいことが明らかである。

海水中 TPT 濃度を $0.45 \mathrm{ng} / \ell$ (検出限界 $0.9 \mathrm{ng} / \ell$ の $1 / 2)$, TPT の BCF を魚類で3, 500, エビ類で 200 と仮定すると， 海水中 TPT に由来する魚類およびエビ類中の TPT 濃度 は, 魚類で $9 \mathrm{ng} / \mathrm{g}$ 乾重, エビ類で $0.3 \mathrm{ng} / \mathrm{g}$ 乾重と試算さ れる。TBTと同様に魚類およびエビ類による海水から の直接濃縮に由来する TPT 濃度の大和堆で採集された 魚類およびエビ類の TPT 濃度に対する比は魚類で 0.06 (アカガレイ) から 0.18 (アゴゲンゲ) の範囲，またエビ 類では, 0.003 (ホッコクアカエビ） から0.006（アシナ ガイバラモエビ）の範囲であった。すなわち，魚介類へ の TPT の生物濃縮において海水から鰓を通して直接吸 収・濃縮する経路の奇与が TBTに比較して小さいこと が明らかであった。

\section{5 食物連鎖の栄養段陼と蕃皘浱度との関係}

Fig. 4および5に示したように, 山陰沖合および大和堆 の両水域において TBT 濃度は食物連鎖の栄養段階に関 連した濃度変化を示さないが, TPT 濃度は, 底泥から底 生生物, エビ類を経由して底層魚に至る食物連鎖の栄養 段階の上昇に伴って次第に濃度が高くなる傾向が認めら れた。すなわち, TPT 化合物は食物網を通して次第に濃 縮されるのに対し, TBT 化合物は食物網を通して濃縮 されないことを示す結果であった。この結果は,オラン

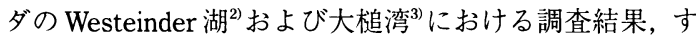
なわち, TPT は動物プランクトンから大型肉食魚へと栄 養段階の上昇に伴ってその濃度が高くなるのに対し， TBT 濃度は栄養段階によって異ならないという研究結 果と同様な傾向であった。TBT と TPT の両化合物の魚 類による蓄積機構が魚類飼育実験により研究され，以下 のようにまとめられている ${ }^{19)}$ 。

(1) TBT 化合物の BCF は TPT に比べて大きく, 水中に溶 
存する TBT は TPTに比較してより蓄積され易い。

(2)一方，経口的に摂取した有機スズ化合物の濃縮係数

(Biomagnification factor: BMF) はTPTで0.57である のに対し, TBTでは0.26〜0.38であり, TPTは TBT に比較して経口的に蓄積され易い。

(3)TBTおよびTPTの魚体からの排泄速度は, それぞれ,

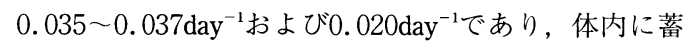
積されたTPT はTBTに比べて排泄され難く, 長期間 残留する傾向である。

以上要約すると, TPTは TBTに比べ, 経口的に蓄積さ れやすいが, 排泄され難い特徴を有する。この TBT と TPT の両化合物の蓄積特性の差異が, これらの化合物の 食物網を通した生物濃縮の差異の原因の一つであると考 えられる。また, 上述したように魚介類の TBT 濃度に 対して海水中 TBT の経鰓濃縮の寄与が大きいために, 魚介類の TBT 化合物濃度は食物連鎖の栄養段階に依存 して高くならないと考えられる。

大和堆で漁獲された各種魚介類中 TBT 濃度の底泥中 TBT 濃度に対する比は, 栄養段階 1 の生物では0.5 5.9 , 特に TBT 濃度の高かったハ夕ハ夕を除くと栄養段 階 2 の生物では0.3〜 5.9, 栄養段階 3 の魚類では0.4〜 7.9であった。魚介類中の TBT 濃度からも明らかなよう に,この比の值は栄養段階の上昇に伴って大きくならな かった。栄養段階 1 の生物では, この比は, モエビ類お よびホッコクアカエビでそれぞれ5.9および4.5であった

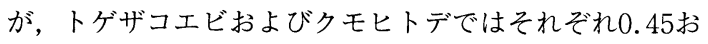
よび0.95であった。すなわち, トゲザコエビおよびクモ ヒトデでは底泥からの濃縮は見られなかった。一方, モ エビ類拉よびホッコクアカエビでは, この比は 1 より大 きいものの後述するようにTPTに比べると小さく, 底 泥堆積 TBT の底生生物への移行 ·蓄積の可能性は TPT
に比べると小さいことが示唆された。

底泥, 飭生物および魚類の食物網における TPT 濃度 の変化を模式的に Fig. 6に示した。底泥からの濃縮係数 はクモヒトデで3.4, トゲザコエビで 9.3 , モエビ類で 9.4, ホッコクアカエビでは19であり, これらの底生生 物が底泥中の TPTを体内に濃縮することが示唆された。 したがって, 底生生物は底泥中の有機スズ化合物を体内 に蓄積するが, 本研究の結果では, 底泥中のTPTに対す る生物体内の濃度比はエビ類で大きく, 底泥の TPT の 食物網を通した再循環においてエビ類が重要であること が考えられる。底泥からエビ類への濃縮係数 (9.3〜19) は, エビ類から栄養段階 2 および 3 の魚介類への濃縮係 数 (ホッコクアカエビからセッパリカジカ1.1, アシナ ガイバラモエビからアカガレイ 3.5 おびホッコクアカ エビからズワイガニ3.7）に比べても大きく, 底層の食 物網を通したTPTの再循環において底泥からエビ類へ の移行が重要であることが示唆された。

本研究の結果は, 底泥に堆積する有機スズ化合物が底 泥を巡る食物網を通して再循環することを示唆するもの であった。したがって，沿岸域および沖合域のいずれに おいても，海水だけでなく底泥中の有機スズ化合物にも 着目した污染対策の推進が必要であると考えられる。

\section{要 約}

TBT およびTPT は日本海沖合域底層まで分布してい た。同海域における底層水の TBT 濃度は0.3〜0.8ng/ $\ell$, TPT 濃度は検出限界 $(0.9 \mathrm{ng} / \ell)$ 以下であった。底泥の TBT およびTPT 濃度は, それぞれ4.4〜16および3.9〜 $7.4 \mathrm{ng} / \mathrm{g}$ 乾重であった。同海域で漁獲された魚介類中の TBT およびTPT 濃度は, それぞれ1.8〜240および5.0〜 $460 \mathrm{ng} / \mathrm{g}$ 乾重であった。胃内容物より解析した栄養段階

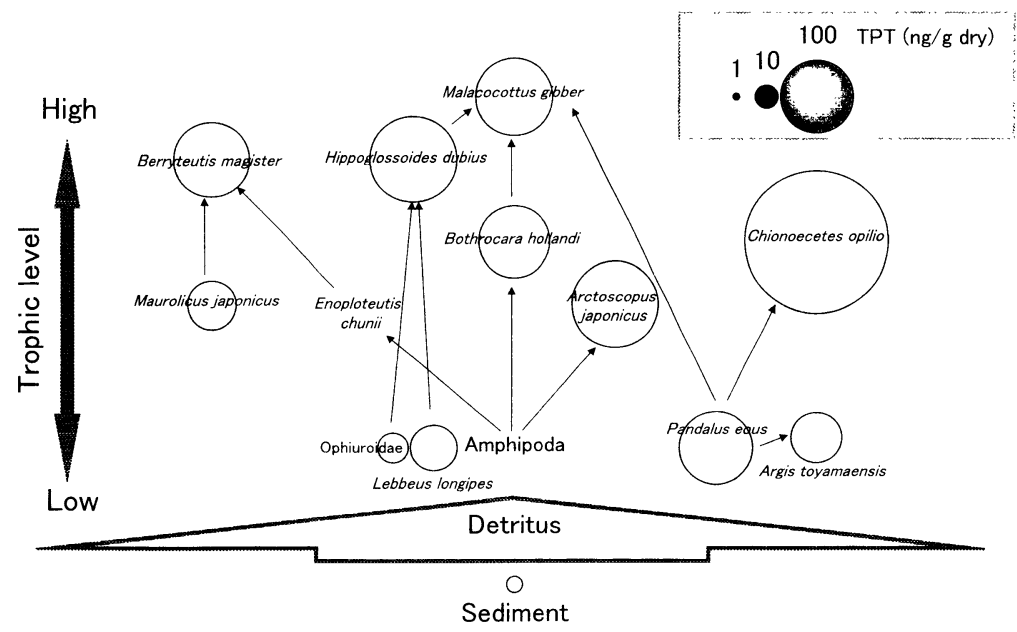

Fig. 6 Bioaccumulation of TPT through the food web developed in the deep water of Yamatotai (B) 
との関係を調べたところ, 魚介類中 TPT 濃度は高次の 栄養段階に位置する種ほど高く, TPT は食物網を通して 濃縮されることが明らかであった。一方, 魚介類中 TBT 濃度と栄養段階との関係は明暸でなく, TBTでは食物 網を通した濃縮が認められなかった。この差は，水生生 物における蓄積・排泄機構が TBT と TPT で異なるため と考えられた。底泥のTPTは底生生物へ移行し, 底泥一 底生生物間の濃縮係数は, 底生生物一捕食者間の濃縮係 数より大きかった。したがって，食物網を通したTPTの 再循環において底泥から底生生物への移行過程が重要で あると考えられた。

\section{文 献}

1) Tanabe, S., Tanaka, H. and Tatsukawa, R.: Polychlorinatedbiphenyls, DDT, and hexachlorocyclohexane isomers in the western North Pacific ecosystem. Arch. Environ. Contam. Toxicol., 13, 731-738 (1984)

2) Stab, J.A., Traas, T.P., Stroomberg, G., van Kesteren, J., Leonards, P., van Hattum, B., Th. Brinkman, U.A. and Cofino, W.P.: Determination of organotin compounds in the food web of a shallow freshwater lake in the Netherlands. Arch. Environ. Contam. Toxicol., 31, 319-328 (1996)

3) Takahashi, S., Tanabe, S., Takeuchi, I. and Miyazaki, N.: Distribution and specific bioaccumulation of butyltin compounds in a marine ecosystem. Arch. Environ. Contam. Toxicol., 37, 50-61 (1999)

4）田辺信介，立川 涼：沿岸域および河口域における 人工有機化合物の動態, 沿岸海洋研究ノ一ト, 19, 9-19（1981）

5）山田 久: 有害物質污染, pp50-71, 「水産と環境」, 清水 誠編集, 恒星社厚生閣, 東京 (1994)

6）山田 久：有機スズ化合物の海域環境における挙動 と魚類による生物濃縮に関する研究, 瀬戸内水研 報, 1，97-162（1999）

7) Takahashi, S., Lee, J.S., Tanabe, S. and Kubodera, T.: Contamination of deep-sea organisms from $\mathrm{Su}$ ruga Bay, Japan by organochlorine and butyltin compounds. National Science Museum Monographs, 12, 331-336 (1997)

8) Takahashi, S., Tanabe, S. and Kawaguchi, K.: Organochlorine and butyltin residues in mesopelagic myctophid fishes from the western north Pacific. Environ. Sci. Technol., 34, 5129-5136 (2000)

9) Berg, M., Arnold, C.G., Muller, S.R., Muhlemann, J. and Schwarzenbach, R.P.: Sorption and desorption behavior of organotin compounds in sedimentpore water systems. Environ. Sci. Technol., 35,
3151-3157 (2001)

10) Webb, J.E., Dorjes, D.J., Gray, J.S., Hesseler, R.R., van Andel, Tj.H., Werner, F., Wolff, T. and Zijlstra, J.J.: Organisms - sediments relationships (Working Group Reports - Group E). pp273-295, "The Benthic Boundary Layer" Edited by McCave, I.N., Plenum Press, New York and London (1976)

11) Harino, H. and Fukushima, M.: Simultaneous determination of butyltin and phenyltin compounds in the aquatic environment by gas chromatography. Anal. Chem. Acta, 264, 91-96 (1992)

12）高見勝重, 奥村為男, 山崎裕康, 中本雅雄 : ガスク ロマトグラフィーによる魚介類中トリフェニルスズ 及びトリブチルスズ化合物の定量, 分析化学, 37, 449-455 (1988)

13）窪寺恒己：イカの生理・生態, pp33-67,「イカーそ の生物から消費までー」, 奈須敬二, 奥谷喬司, 小 倉通男共編著, 成山堂, 東京 (1991)

14) Yamada, H., Takayanagi, K., Tateishi, M., Tagata, H. and Ikeda, K.: Organotin compounds and polychlorinated biphenyls of liver in squid collected from coastal waters and open oceans. Environ. Poll., 96, 217-226 (1997)

15）田尾博明, 長縄竜一, 中里哲也, 富永衛, 大 柣 晃, 橋本伸哉：東アジア海域における有害化学 物質の時空間変動機構に関する研究, pp49-68,「東 アジア海域における有害化学物質の起源と蓄積に関 する研究, 環境庁地球環境研究総合推進費終了報告 書, 東アジア海域における有害化学物質の動態解明 に関する研究」, 環境庁, 東京 (2000)

16）環境省環境保健部環境安全課：第 5 部平成11年度有 機スズ化合物に関する環境調査結果の概要, pp245265 ,「平成12年度版化学物質と環境」, 環境省, 東 京 (2000)

17) Yamada, H. and Takayanagi, K.: Bioconcentration and elimination of bis(tributyltin) oxide (TBTO) and triphenyltin chloride (TPTC) in several marine fish species. Water Res., 26, 1589-1595 (1992)

18）堀 英夫，立石晶浩，山田 久：閉鎖循環式試験装 置を用いた長期飼育試験による有機スズ化合物のク ルマエビへの生物濃縮, 日本水産学会誌，68，3745 (2002)

19) Yamada, H., Tateishi, M. and Takayanagi, K.: Bioaccumulation of organotin compounds in the red sea bream (Pagrus major) by two uptake pathway: Dietary uptake and direct uptake from water. Environ. Toxicol. Chem., 13, 1415-1422 (1994) 